Maria Pia Paternò

Università di Camerino, Italy

\title{
BEYOND TOTALITARIANISM: POLITICS, RELATIONALITY AND NARRATIVITY
}

\section{The Self and its relationality to the world}

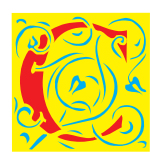

ontemporary political philosophy has repeatedly underlined the inadequacy of western political anthropology and its supposedly rational, autonomous and self-sufficient Self. It has rejected the untenable account of a sovereign subject and underlined man's needs for relationship and nurturance as well as the complex bonds of interdependence which arise from his vulnerable and fragile constitution. ${ }^{1}$ A relevant impulse towards this goal has been given by feminist works on philosophy and anthropology, which have stressed the natural dependency of man and the unsaid gender biased prejudices that characterise western modern ethics as well as its political thought and underlying public/private split.

I have from time to time hinted at the relevance of a feminist approach to politics and society. ${ }^{2}$ My actual interest turns, nonetheless, to a different strand of thought, which construes man's subjectivity on relationality but does not pay any specific attention to gender and is scarcely sensible to the political potentialities of the feminine. I am referring to Günther Anders, Hannah Arendt's first

${ }^{1}$ In the context of the Italian philosophical and political theory, particularly relevant are the works of E. Pulcini and A. Cavarero. Cfr. E. Pulcini, The Individual without Passions. Modern Individualism and the Loss of Social Bond, Lanham: Lexington Books, 2012; Ead., Care of the World. Fear, Responsibility and Justice in the Global Age, Dordrecht: Springer, 2012. As for Adriana Cavarero, cfr. Relating Narratives: Storytelling and Selfhood, London \& New York: Psychology Press, 2000.

2 M. Pia Paternò, Dall'eguaglianza alla differenza. Diritti dell'uomo e cittadinanza femminile nel pensiero politico moderno, Milano: Giuffrè, 2008; Ead., Donne e Diritti. Percorsi della politica dal Seicento a oggi, Roma: Carocci, 2012. 
husband, who discussed at length with his wife the topic of subjectivity and man's relationality to the world. ${ }^{3}$

Unlike Arendt, Anders is all but famous; particularly so in Anglo-Saxon countries. This is due to the fact that his major philosophical work, Die Antiquiertheit des Menschen, has never been translated into English. The only philosophical works we can read in English are an essay on Heidegger's Philosophy and a youth essay — "The Pathology of Freedom"- the translation of which only dates back to 2009. No wonder that-the French and Italian translations of his work notwithstanding - Anders is not known world-wide.

"The Pathology of Freedom" is the English translation of one of the two essays published in French in the Thirties: one of which has been translated by Emmanuel Levinas. ${ }^{4}$ Due to the Nazi takeover in 1933, Anders was obliged to escape from Germany and lived in Paris as a refugee until 1936, when he moved to the United States. At the time of his exile in France he had occasion to attend the famous lectures that Alexandre Kojève was delivering on Hegel at l'École pratique des hautes Études. Many later maitres-à-penser met there: George Bataille and Jacques Lacan among them. There was much talk of Hegel's conceptions of Reason and of Man: a subject which, in Kojève's words, distinguishes himself from animals due to his immaterial needs and his desire for recognition. ${ }^{5}$

There is no massive reference, in Anders' works, to Hegel's master-slave dialectic which Kojève exposed during his lessons in the late Thirties, at a time when Anders had already moved to America. But his "Pathology of Freedom" gives us some important hints related to his stance on the subject and the world he lives in. According to his idea, the difference between man and animals is due to man's "basislessness": ${ }^{6}$ whereas animals instinctively know the world, man lacks a comparable Integrations-Koeffizient. According to Anders "man does not foresee his world [...] He is not cut for any material world, cannot antici-

3 G. Anders, Die Kirchenschlacht: Dialoge mit Hannah Arend, G. Oberschlick (ed.), München: Beck, 2011.

${ }^{4}$ Anders had presented in 1930 before the Kant Society of Frankfurt and Hamburg: Die Weltfremdheit des Menschen. At the time of his exile in France Levinas translated the first 24 pages of the manuscript and let it be published in Recherches Philosophiques, IV, 1934-5 with the title Une interprétation de l'a-posteriori.

5 A. Kojève, Introduction to the Reading of Hegel, Ithaca \& London: Cornell University Press, 1969.

6 G. Anders, "On the Pseudo-Concreteness in Heidegger's Philosophy", Philosophy and Phenomenological Research, 3 (1948), 346. 
pate it in its determination [...] he needs experience [...] to put it paradoxically, artificiality is the nature of man and his essence is instability."

It is on this specific anti-essentialistic conception of man that I will try to build my own argument. I will do so by entwining this anthropology with some interesting points advanced in contemporary psychoanalysis and literature. I will therefore try to knot Anders' arguments together with those presented by a leading Italian Lacanian psychoanalyst Massimo Recalcati and to an Italian literate: Pier Paolo Pasolini. There are strong objective bonds between these authors who share a similar interpretation of western post-World War Two consumer societies. They targeted them defiantly as "totalitarian": a sort of totalitarianism that is stripped of its ferocious mask and whose violence makes no use of terror. They referred to a soft, ${ }^{8}$ scientist, postmodern or post-ideological totalitarianism: ${ }^{9}$ but did not shrink before the actualisation of this word. Anders went so far as to speak of a "totalitarianism of pleasure" whereas Recalcati actualises Lacan's "jouissance" so as to talk of a "totalitarismo del godimento": ${ }^{10}$ our hypermodern times are depicted as strongly resembling mid-century Nazi or Soviet totalitarianism because of their common absence of limits and successful—albeit extremely differently obtained — annihilation of liberty and "desire". Rather the particular problem they refer to is not the "Captive Mind", as depicted in Milosz's masterpiece. The kind of totalitarianism they have in mind-albeit soft, is a much more far reaching one: it entails a dominion which is not prevalently exercised upon the minds of the people since it affects their feelings, bodies and wills.

\section{The risk of a new totalitarianism}

Neither Anders nor Pasolini or Recalcati were the first to denounce the analogies existing between "traditional" totalitarian States and the specific totalitarianism of democratic societies. But what is here at stake is a particular

7 G. Anders, "Pathology of Freedom. An Essay on Non-Identification," in: The Life and Work of Gunther Anders. Emigré, Iconoclast, Philosopher, Man of Letters, G. Bischof, J. Dawsey, B. Fetz (eds.), Wien: Studien Verlag, 2014, 145-146.

${ }^{8}$ G. Anders, Die Antiquiertheit des Menschen, Band II, München: Beck, 1980.

9 M. Recalcati, L'uomo senza inconscio. Figure della nuova clinica psicanalitica, Milano: Cortina, 2010, 320.

10 Ibidem, 324. 
version of this attention to the totalitarian dimension within the liberal democracies of our contemporaneity; one which holds on to the critique of the instrumental reason as theorised by Horkheimer and Adorno, but is rather sceptical about the possibility that subjects might individually free themselves through the liberation of the "pleasure principle", as envisaged in Eros and Civilization. No "narcissistic" revolution à la Marcuse is conceived by any of them ${ }^{11}$ to dispose of the Promethean man who is, in his own words, the archetype-hero of the performance principle. ${ }^{12}$

Anders, Pasolini and Recalcati share one common belief: man has undergone such relevant changes in present consuming societies that nothing short of a reference to an-already occurred-anthropological revolution would do to adequately name this new state of things. ${ }^{13}$ The revolution they are speaking of has not freed the individual and liberated the pleasure principle; it has rather enslaved man with chains he himself is eager to impose on himself. That is why they give Marcuse's talk of a repressive desublimation ${ }^{14}$ a somewhat different—and even more disquieting—shading: whereas he had hinted at the fact that hyper-hedonism strips enjoyment of any limit but enhances, in fact, the realty of dominion, the focus of Pasolini's, Anders' and Recalcati's attention is positioned both on the restrictions of liberty and on their enhancing effect on pleasure (Anders) and enjoyment (Lacan, Recalcati). Although they all accurately describe the concealment of coercion which takes place in consumer societies, they also focus their attention on the particular kind of (perverse) pleasure which illiberty is capable of producing.

Consider Anders, who was so well acquainted with Marcuse that they even shared the same home for a short while, at the time of their American exile in the Forties. His point of view is that science and technology have completely

${ }_{11}$ M. Recalcati, Elogio dell'inconscio. Dodici argomenti in difesa della psicanalisi, Milano: Bruno Mondadori, 2007, 55-63. As for Anders, see P. P. Portinaro, Il principio disperazione. Tre studi su Günther Anders, Torino: Bollati e Boringhieri, 2003, 141.

${ }_{12}$ H. Marcuse, Eros and Civilization, A Philosophical Enquiry into Freud, Boston: Beacon Press, 1955.

13 G. Anders, Die Antiquiertheit des Menschen, Band 1, München: Beck, 1956, 239: "wir sind nun nicht einfach nur Vertreter einer neuen geschichtlichen Generation von Menschen, sondern, obwohl anatomisch natürlich unverändert, durch unsere völlig veränderte Stellung im Kosmos und zu uns selbst, Wesen einer neuen Spezies". Cfr. P. P. Pasolini, Lutheran Letters, New York: Carcanet Press, 1987, 33.

${ }^{14}$ H. Marcuse, One-Dimensional man. Studies in the Ideology of Advanced Industrial Societies, London: Routledge, 1964. 
revolutionised society in the Twentieth Century: neither the homo faber nor the homo creator have their place in it anymore; they have been ousted by the homo materia, a new-sprung kind of man who is devoid of any personal will and completely subjected to the imperatives of technology. ${ }^{15}$ Anders therefore argues in favour of a re-consideration of democracies and emphasises the abundance of restrictions on liberty taking place within them as a consequence of the endless possibilities provided by new technologies: totalitarianism, he argues, should not primarily be thought of as something referring to some authoritarian states; it rather identifies the specific trend and the real nature of technique. In the totally brain-washed US population, every subjectivity is simply and radically "cancelled", he announces. Violence and loss of freedom have reached such an absolute degree of perfection in the soft versions of totalitarianism, that there is no use of terror (and absolutely no need of it) in these so-called democracies: "nowadays Hitler and Stalin are superfluous", because subjection is already a fait accompli, making orders and prohibitions simply not necessary ${ }^{16}$ any longer.

A totalitarianism of pleasure is therefore ensuing from democratic consumer societies: Anders prognostic here joins the analysis of both Recalcati and Pasolini. The point the latter makes in his Scritti corsari, is that post World War new fascism - or totalitarianism-is a more insidious and destructive form, which assimilates and homologises every difference among men through consumerist levelling. The new culture of consumer societies is the most repressive totalitarianism ever seen, ${ }^{17}$ he argues, pointing to the fact that it imposes a cruel and degrading conformism that changes the very nature of the people and burrows into the inner depth of their conscience. That's why in his pedagogic work-Gennariello- he urged his contemporary Neapolitan double of Rousseau's Émile, to reject any culture of degradation and refuse any acceptance ${ }^{18}$ of a society where enjoyment is transformed in an imperative that does not liberate life; rather, it enslaves it.

These critiques of western hyper-materialism and of its subsequent loss of liberty are highly valued in the works of Massimo Recalcati, who identifies in Pasolini's movie Salò o le 120 giornate di Sodoma a good account of the pathologies arising in capitalistic societies through the excesses they foster and the constraint they covertly exercise. Recalcati's point of view is enriched with some

\footnotetext{
15 G. Anders, Die Antiquiertheit..., II, 14, 17.

16 Ibidem, 131-187. am2, 178-9.

17 P. P. Pasolini, Scritti corsari..., Milano: Garzanti, 1975, 126.

18 P. P. Pasolini, Lutheran Letters..., 24.
} 
Lacanian intuitions, which confer to his texts a different insight to our present discontent and the psychological pathologies flourishing in our environment. His main concern is devoted to the consequences of today's pathological dependency on consumption, whereby people are reduced to bare instruments of enjoyment deprived of any restraint, which cancels desire and enslaves life in an ever repeating compulsion. This perverse post-ideological enjoyment is analysed both in its inmate void and consequences vis à vis of desire. ${ }^{19}$ According to the psychoanalytic understanding of desire as a sentinel of the Unconscious, Recalcati stresses its role in defying any adaptation to the "principle of reality" and shows great concern for the consequences of its collapse in western capitalism: its eclipse is said to have brought about a new kind of slavery in which people (deprived of their unconscious selves), are condemned to pursue a flat and nihilistic enjoyment centred on a compulsive consumption which leaves them constantly unsatisfied and enhances atomisation and self-seclusion. Leaning on Lacan's theories, Recalcati depicts today's totalitarianism as an "inner catastrophe" ${ }^{\prime 20}$ which is the consequence of an effacement of the singularity of the subject and oblivion of the irreducibility of desire.

\section{In lieu of a conclusion: learning from Günther Anders' narrative approach}

The descriptions of totalitarianism taken into account face us with a number of problems on both the theoretical and political level. Not only do they force us to take conscience of the doubtful usefulness of such an enlarged concept of totalitarianism, but they also leave us with little hope in politics: either ban it altogether and ask for a heroic resistance deprived of any perspectives in the future; or else look for hope within domains that could hardly be properly defined as political.

Conscious of this difficulty and willing to explore new paths of research, I suggest here a weak version of a possible use of politics today. In order to express it, I will be basing it on the kind of political-philosophical reporting which characterised Anders' writing activity in the Sixties. After having licensed

19 M. Recalcati, L'uomo senza inconscio, 320; ID., L'eclissi del desiderio, in: Forme contemporanee del totalitarismo, Torino: Bollati Boringhieri, 2007, 61-79.

20 The Seminar of Jacques Lacan. Book VII, The Ethics of Psychoanalysis, 1959-1960, New York and London: Norton \& Company, 1992, 327. 
the first volume of his major philosophical text-Die Antiquiertheit der Menschheit-Anders devoted his attention to a series of political events, to which he afforded a narrative style, mixing personal experiences and psychological insights with political events and rational judgment. He wrote on the Vietnam War, the space race, the destruction of Europe and the bombing of Hiroshima and Nagasaki.

On top of these mentioned works are two publications which consist of two remote dialogues: one with the son of a Nazi criminal who was at the time on trial in Jerusalem ${ }^{21}$ (and who never answered to Anders' urging plea for a public standing on the question of guilt); and the other with one of the pilots who had taken part in the bombing of Hiroshima ${ }^{22}$ and who in the aftermath seemed unable to cope with the consequences of his deed. Unlike Eichmann's son, the latter corresponded at length with Anders, giving occasion to a rich correspondence which went as far as to involve America's President John Fitzgerald Kennedy. In applying to Eatherly's affair the conceptual categories he had worked out in his philosophical works, Anders not only helped Eatherly to come out of the psychiatric hospital in which he had been detained following several episodes of sociopathic behaviour, but provided ample proof of some of the risks entailed in technology and in an acritical acceptance of mere ideological discourses. Anders' understanding of the American pilot's uncanny behaviour helped both him and his readers to afford the question of the possibility of politics and investigate the new-albeit meagre — forms of responsibility and advocacy still available in the context of techno-totalitarian consumerist societies, where the discrepancy between man's hypertrophic productive capacity and his less advanced capability for feeling and perception is at its climax. Anders therefore considered Eatherly's failure to cope with his conscience as good news: his mental disease certified that there still was some hope that man could become aware of his responsibilities and have a chance to recover the discrepancy between his capability of producing things and his scarce ability in reproducing them mentally.

Through his political narrative Anders himself aimed at contributing to this goal. He, proved there exists (however small) a chance to contribute to the fulfilment of the specific task, had envisaged for philosophy in his own 1964.

${ }^{21}$ G. Anders, Wir Eichmannsohne. Offener Brief an Klaus Eichmann, München: Beck,

${ }^{22}$ G. Anders, Burning Conscience. The Case of the Hiroshima Pilot Claude Eatherly told in his Letters to Gunther Anders, Hamburg: Rowohlt Verlag, 1961. 
days: the task of working at an enlargement of moral fantasy. ${ }^{23}$ But to do so, he argued, it is necessary to be aware of the superliminal: an effect occurring in the face of too great or too much distressing phenomena, which blur man's capacity for evaluation and judgment. Through this political narrative Anders aims therefore at re-individualising numbers and supplementing any mere intellectualistic perception with those essential components of comprehension provided by feeling and imagination. ${ }^{24} \mathrm{He}$ intervenes-politically-as the guardian of a fiction which provides us with facts ${ }^{25}$ we would not have been able to detect ourselves due to the difficulties entailed in the perception of events "that we can produce more than we can mentally reproduce" and which are too distant or "too big for our imagination and the emotional forces at our disposal." ${ }^{26}$ Through narrative these facts can be recovered: reducing their magnitude the story-teller can preserve them and make them accessible: it is only through a "fiction" that—in our present context—facts can be made clear and understandable. ${ }^{27}$ That was how Anders contributed to the non-renounceable task of building bridges between man's hopes and the real world ${ }^{28}$ in which he lives, empowering imagination so as to envisage the consequences of his actions.

\section{References}

Anders, G., Burning Conscience. The Case of the Hiroshima Pilot Claude Eatherly told in his Letters to Gunther Anders, Hamburg: Rowohlt Verlag, 1961.

Anders, G., Die Antiquiertheit des Menschen, Band I, München: Beck, 1956.

Anders, G., Die Antiquiertheit des Menschen, Band II, München: Beck, 1980.

Anders, G., Die Kirchenschlacht: Dialoge mit Hannah Arend, G. Oberschlick (ed.) München: Beck, 2011.

Anders, G., "Nach Holocaust," Besuch im Hades [1979], München: Beck, 1997.

Anders, G., "On the Pseudo-Concreteness in Heidegger's Philosophy," Philosophy and Phenomenological Research 3 (1948), 337-371.

\footnotetext{
23 G. Anders, Antiquiertheit..., I, 271-293.

${ }_{24}$ G. Anders, Nach "Holocaust" 1979, in: Besuch im Hades, München: Beck, 1997, 201.

25 Ibidem, 202-203.

26 G. Anders, Burning conscience..., 3-4.

27 G. Anders, Nach "Holocaust" 1979, 181: "Nur durch fictio kann das factum, nur durch Einzelfälle das Unabzählbare deutlich and unvergessbar gemacht werden".
}

28 G. Anders, Burning conscience..., 86. 
Anders, G., "Pathology of Freedom. An Essay on Non-Identification," The Life and Work of Gunther Anders. Emigré, Iconoclast, Philosopher, Man of Letters", G. Bischof, J. Dawsey, B. Fetz (eds.), Wien: Studien Verlag, 2014, 145-170.

Anders, G., Wir Eichmannsohne. Offener Brief an Klaus Eichmann, München: Beck, 1964.

Cavarero, A., Relating Narratives: Storytelling and Selfhood, London and New York: Psychology Press, 2000.

Kojève, A., Introduction to the Reading of Hegel, Ithaca \& London: Cornell University Press, 1969.

Lacan, J., The Seminar of Jacques Lacan, Book VII, The Ethics of Psychoanalysis, 1959-1960, J. Alain-Miller (ed.), New York and London: Norton \& Company, 1992.

Marcuse, H., One-Dimensional man. Studies in the Ideology of Advanced Industrial Societies, London: Routledge, 1964.

Pia Paternò, M., Dall'eguaglianza alla differenza. Diritti dell'uomo e cittadinanza femminile nel pensiero politico moderno, Milano: Giuffrè, 2008

Pia Paternò, M., Donne e Diritti. Percorsi della politica dal Seicento a oggi, Roma: Carocci, 2012.

Pulcini, E., Care of the World. Fear, Responsibility and Justice in the Global Age, Dordrecht: Springer, 2012.

Pulcini, E., The Individual without Passions. Modern Individualism and the Loss of Social Bond, Lanham: Lexington Books, 2012.

Recalcati, M., Elogio dell'inconscio. Dodici argomenti in difesa della psicanalisi, Milano: Bruno Mondadori, 2007.

Recalcati, M., L'uomo senza inconscio. Figure della nuova clinica psicanalitica, Milano: Cortina, 2010.

Recalcati, M., L'uomo senza inconscio, L'eclissi del desiderio. Forme contemporanee del totalitarismo, Torino: Bollati Boringhieri, 2007. 